\title{
Kierunki, zwroty i przystanki
}

Anna Nasiłowska 


\section{Wstęp}

\section{Kierunki, zwroty i przystanki}

Anna Nasiłowska

TEKSTY DRUGIE 2017, NR 4, S. 9-12

DOI: $10.18318 /$ td.2017.4.1

$\mathbf{0}$ d długiego czasu mam wrażenie, że gdyby ktoś chciał bez reszty podporządkować swoje życie intelektualne rytmowi kolejnych zwrotów w humanistyce, jakie ogłasza i projektuje nasze pismo - pogrążyłby się $w$ chaosie albo by zwariował. Nie dlatego, że owe zwroty zawierają postulaty niemożliwe do spełnienia, ale dlatego, że kolejne fale następują zbyt szybko, zbyt szybko jeden po drugim, a samo zarysowanie jakiejś postawy nie wystarcza, by w pełni wykorzystać konsekwencje teoretycznego zwrotu w praktyce. Potrzebne są zatem i takie numery, które nie ogłaszają kolejnego przełomu, ale zdają sprawę z poszukiwań i badań, które się już toczą. Niniejszy numer nie jest zresztą wyłącznie składanką, czyli silva rerum, linie wspólne są wyraźne i czytelnik je z pewnością dostrzeże.

Szybkie tempo sprawia też, że czasami jakiś istotny element umyka. Wydawałoby się, że przyswoiliśmy wszystko, co ważne, z kręgu francuskiej humanistyki... A jednak - nie do końca. Jest polskie tłumaczenie Rolanda Barthes'a Fragmentów dyskursu miłosnego, nie ma polskiej wersji Histoires d'amour Julii Kristevej. Pierwsze wydanie ukazało się w wydawnictwie Gallimard w 1983 roku, w Polsce mieliśmy wtedy trochę inne problemy, raczej polityczne niż miłosne. A i teraz atmosfera nie jest przyjazna, wystarczy przeczytać poświęcone autorce hasło w polskiej Wikipedii, w którym przypisuje się jej - poza nieuctwem - marksizm.

\section{Anna}

Nasiłowska - prof. dr hab., pracownik IBL PAN, członkini Zespołu Literatura i Gender IBL PAN. Zastępca redaktora naczelnego „Tekstów Drugich". Ostatnio opublikowała biografię Marii Pawlikowskiej-Jasnorzewskiej (2010), wybór pism Stefanii Zahorskiej (2010), reportaż historyczny Wolny agent Umeda idruga Japonia (2013), tom poezji Żywioły (2014) oraz Dyskont słów (2016). Współredaktorka Encyklopedii gender (2014). Kontakt: anna. nas@wp.pl 
We Francji Histoires d'amour były wielokrotnie wznawiane, także w wydaniu masowym, kieszonkowym i książka wpisuje się w tradycje intelektualne, które u nas przeważnie występują jako odrębne nurty, jak psychoanaliza i badania poststrukturalne. Bardzo się ucieszyłam, gdy odkryłam w jednym z artykułów to odwołanie, co prawda nie do oryginalnej wersji francuskiej, ale do amerykańskiego tłumaczenia - takie to czasy, nawet Derrida bywa tłumaczony via Ameryka, choć to droga okrężna i niebezpieczna. Jak niebezpieczna miałam się okazję przekonać wiele lat temu, gdy tłumacząc (dla „Tekstów Drugich") manifest Hélène Cixous Śmiech Meduzy, usiłowałam wspomóc się tłumaczeniem amerykańskim. Szybko zaprzestałam, wersja amerykańska odznacza się daleko idącą symplifikacją. Natomiast Histoires d'amour oddziałały na mnie tak mocno, że są jednym z powodów powstania mojej książki prozatorskiej Historie miłosne, którą oczywiście odczytywano, przywołując Barthes'a. Tymczasem Fragmenty dyskursu miłosnego są dość kostycznym esejem, podporządkowanym jednej tezie o samotności zakochanego, a książka Kristevej - wielostronnym, pogłębionym psychoanalitycznie i historycznie opisem fenomenu, w którym trudność (ale nie - niemożność) mówienia stanowi jeden z rysów „prywatnego kataklizmu”, który wstrząsa podstawami dobrego samopoczucia ustabilizowanego podmiotu. Bowiem „w miłości /a staje się kim innym" - co nawiązuje do sławnej formuły Rimbauda z listu do Paula Demeny, tzw. listu jasnowidza: moi c'est un autre, a tym samym - odwołuje się do podstaw poezji nowoczesnej i wydobywa poetycką, metaforyczną naturę uczucia naznaczonego koniecznym tragizmem i nieusuwalnym cierpieniem. Cierpienie wynika z zakorzenienia w narcyzmie i idealizacji.

Już Freud zetknął się dość boleśnie z naturą miłości, gdy uczucia zaczęły mu wyznawać zakochane $w$ nim pacjentki. Bronił się formułą, że to nie on jest obiektem, jest nim X, idealizacja przeżywana przez pacjentkę, która dokonuje nieuprawnionego przemieszczenia. Przejście między idealizacją a realnością, w której jest miejsce na seks, nie jest ani automatyczne, ani konieczne. Problem idealizacji ma według Julii Kristevej drugie dno - metafizyczne, platońskie. Sama idealizacja według Lacana wiąże się ściśle z narodzinami „ja” w trakcie "stadium lustra”, jak twierdzi: „Ludzkie ja tworzy się w oparciu o relację wyobrażoną". W moim egzemplarzu Histoires d'amour Kristevej znajduję podkreślone kiedyś zdanie: „Zakochany to narcyz, który znalazł sobie obiekt".

Odrębnym problemem, który wiąże się z szybko następującą wymianą koncepcji badawczych i szkół myślenia na coraz nowsze, jest pozycja tych tradycji, które są stare - jak metody filologicznego opracowania edytorskiego tekstu, wywodzące się z epoki hellenistycznej. Dawne tradycje płynnie wzbogacają się o nowe ujęcia, nie zawsze więc formuła zwrotu jest właściwa. W szczególny sposób widać to także na przykładzie biografistyki, której także przypisuje się rodowód starożytny - od Plutarcha i Swetoniusza. Biografia ma oczywiście swoją brytyjską wersję modernistyczną, związaną 
z twórczością Lyttona Stracheya, ale i to było dawno, prawie sto lat temu - jego podstawowa i przełomowa dla gatunku nowoczesnej biografii książka Eminent Victorians ukazała się w roku 1918. U nas przetłumaczona została w połowie, dwa szkice (precyzyjne, wspaniale operujące ironią) ukazały się w 1939 roku, przy czym wydawnictwo zapowiadało szybką kontynuację w następnym tomie. Nie trzeba tłumaczyć, z jakich powodów ta zapowiedź nie została nigdy spełniona. Tradycja tego typu ujęć była jednak dobrze znana w Polsce przed wojną, przede wszystkim za sprawą François Mauriaca, gdyż inspiracje krążyły wtedy inaczej, docierając najłatwiej via Francja.

Po wojnie w Polsce biografia, łączona z genetyczno-pozytywistycznym podejściem, które zostało przezwyciężone, długo była na cenzurowanym. Ponieważ historykom literatury była jednak potrzebna, wypracowano typ dość skromnego, rzeczowego kalendarium, przykładem są tu prace Józefa Szczublewskiego, pozbawione spajającej fakty narracji (jego biografie Sienkiewicza, Osterwy czy Modrzejewskiej, nazywane „żywotami"). Biografia ma tradycję, nie ma ekscytującej intelektualnie nowej teorii, bardzo wiele zależy bowiem od wyników poszukiwań archiwalnych i typu materiałów, jakimi się dysponuje. James L. Clifford, autor przetłumaczonej u nas uroczej gawędy Od kamyków do mozaiki, twierdził, że jest to jedyny gatunek, któremu teoria nie jest potrzebna i nie warunkuje osiągnięcia sukcesu.

Tak czy inaczej biografia jest u nas obecnie jedynym gatunkiem humanistycznym czy też typem profesjonalnego pisarstwa, który przekracza granice kręgu profesjonalnych odbiorców i może osiągać spore nakłady. W Polsce taka pozycja gatunku to coś zupełnie nowego. Postępujący jednocześnie coraz wyraźniejszy kryzys eseju, a także zjawisko zaniku krytyki literackiej w związku z coraz gorszą kondycją prasy literackiej sprawiają, że pewne dyskusje literackie albo przestały się toczyć, albo - zaczęły toczyć się inaczej. Przygotowana przez Andrzeja Franaszka biografia Zbigniewa Herberta (której niewielki fragment prezentujemy) zapewne poruszy problemy, które były dyskutowane od lat 8o., w sporach o interpretacje wierszy poety, a zarazem o postawy polityczne i wybory tradycji kulturowych. Wielką szansą biografistyki jest dystans wobec publicystycznych, mocno zideologizowanych ujęć, które upraszczają i sprowadzają rozumienie poety do kilku haseł. 


\section{Abstract}

\section{Anna Nasiłowska}

THE INSTITUTE OF LITERARY RESEARCH OF THE POLISH ACADEMY OF SCIENCES (WARSAW)

Directions, Turns and Stops

This issue brings together ongoing research on a variety of positions and theoretical turns as outlined above. New inspirations demand deeper and further research. Another problem is the need for further research in philology and biography. Theoretical impulses were not the reason for the rebirth of biographical writing in Poland, which for several years now has enjoyed immense popularity among readers.

\section{Keywords}

turns in the humanities, philology, biography 